\title{
Editorial: The Hannah Research Institute
}

\author{
Christopher H Knight*
}

University of Copenhagen Faculty of Medical Sciences, DK1870 Frb C, Denmark

It is a year since the Journal of Dairy Research first published an Editorial. For someone living in the UK, when one takes into account special relationships with Europe and North America it has been a year of considerable change, the outcomes of which are yet to be understood. As far as the Journal is concerned, I hope that the changes we have made (such as online submission and Peer Review, Research Communications, Review Articles) have been beneficial to you, our scientific readership. The latest change can be seen on the hardcopy version of this February issue; a new front cover design featuring the two cows who have watched over our websites for the last year. Growing up on a family dairy farm, all of our cows had names, prefixed by our pedigree herd name, 'Stonstan'. So, if anyone wishes to propose names for our latest Stonstan recruits, please do! Another less noticeable change to the front cover is the disappearance of the IFR (Institute of Food Research) logo, reflecting the fact that the Hannah Research Foundation is now the sole owner of the Journal. This would seem an appropriate time at which to reflect briefly on 'the Hannah'.

"Last month the Secretary of State for Scotland opened the Hannah Research Institute with a view to studying the whole set of problems, animal and human, that are summarized in the one word - milk"

In 1978, JAB Smith published 'A Brief History of the Hannah Research Institute 1928-1978' (Smith, 1978), of which this 1928 recollection is the first paragraph. The history was commissioned by the then Director, John Rook, to commemorate the 50th Anniversary of the founding of the Institute and was accompanied by the simultaneous publication of an impressive collection of scientific essays. Why 'Hannah'? Until 1931 the 'Hannah Dairy' as it was then popularly known was located within the coastal town of Ayr, before moving to its new purpose-built site on the nearby Auchincruive estate, which had been gifted to the nation by the late JM Hannah. When I joined the Hannah in 1979 its full title included the tagline '...for studies relating to the production and utilization of milk' to emphasise what had always been the case, namely that the Institute researched across the length of the dairy foods chain.

"Professor Malcolm Peaker, who is presently Head of the Physiology Department of The Hannah Research Institute, has

*For correspondence; e-mail: chkn@sund.ku.dk been appointed Director of the Institute in succession to Professor J. A. F. Rook. He took up his appointment on 1 April 1981"

This notice appeared in volume 48 of the Journal of Dairy Research (when did we stop publishing notices of this sort, I wonder?) Two years later the Annual Report (Hannah Research Institute, 1983) identified 101 permanent scientific staff (41 concerned loosely with 'production' and 60 with 'utilization'), 25 postgraduate students and a total complement of 160 (not counting around 300 dairy cows of the 'Kirkhill' pedigree herd!) There were extensive links with the local community, the national and international scientific communities, the UK dairy industry and consumers of dairy products worldwide. That 1983 report included a photograph of a bottle of Heather Cream being admired by scientists and politicians: the first stable emulsions of cream and alcohol were invented at the Hannah and now constitute a high-value market approaching $150 \mathrm{M}$ litres annually. On a personal note, this was the year that I spent many quiet hours sitting with sedated goats in the world's first magnetic resonance imager, monitoring the growth of the secretory tissue of the udder.

\section{"Dolly died as this Commentary was being written"}

The Hannah continued to produce Annual Reports until 2003, and this is the opening line of a Commentary that I wrote for that last one (Knight, 2003). As most readers will know, Dolly, the first animal cloned from an adult cell, was born at the Roslin Institute in 1996. Actually, 'Dolly' had been walking our fields at the Hannah for several years before that, since the mammary cell from which she was cloned was produced at the Hannah. Malcolm Peaker retired as Director in 2003, and there followed three years of uncertainty which extended to much of the Scottish agricultural research sector. The eventual outcome was the closure of the Hannah in 2006 and transfer of most of its scientific activity to the University of Strathclyde. The Institute's main building, sitting on an impressive man-made hill, is now luxury apartments and the rest of the brown-field site is residential housing. The philanthropic ethos of enabling research for the benefit of animals and humans continues, however, since the proceeds of the sale were invested and now fund research studentships. In a sense, the Institute also lives on in this Journal, now constituting a truly global community of researchers concerned with the production and utilisation of milk. To emphasise the global and community aspects, this issue includes a 'review' article that introduces the Editorial Board. 


\section{References}

Hannah Research Institute 1983 The Hannah Research Institute for Studies Relating to the Production and Utilization of Milk Report 1983. Ayr: Hannah Research Institute. ISBN 0905151364
Knight CH 2003 From a Healthy Dairy Industry to the Health of the Nation: the Evolving Contribution of Mammary Gland Biology. Hannah Research Institute Yearbook2003. Ayr: Hannah Research Institute. ISBN 0708406521 Smith JAB 1978 A Brief History of the Hannah Research Institute. Ayr: The Hannah Research Institute. ISBN 0905151283 